\title{
Coercing bisphosphonates to kill cancer cells with nanoscale coordination Q2 polymers†
}

\author{
Demin Liu, Stephanie A. Kramer, Rachel C. Huxford-Phillips, Shunzhi Wang, Joseph Della \\ Rocca, and Wenbin Lin \\ Department of Chemistry, CB\#3290, University of North Carolina, Chapel Hill, North Carolina \\ 27599, USA
}

Wenbin Lin: wlin@unc.edu

\begin{abstract}
Nanoscale coordination polymers containing exceptionally high loadings of bisphosphonates were coated with single lipid bilayers to control the drug release kinetics and functionalized with a targeting ligand to endow cell-targeting capability, leading to much enhanced cytotoxicity against human lung and pancreatic cancer cells.
\end{abstract}

Coordination polymers are an interesting class of molecular materials that have found many applications, including gas storage, ${ }^{1}$ catalysis, ${ }^{2}$ nonlinear optics, ${ }^{3}$ chemical sensing,${ }^{4}$ and separations. ${ }^{5}$ When scaled down to the nano-regime, nanoscale coordination polymers (NCPs) have shown promise for applications in biomedical imaging. ${ }^{6}$ NCPs have also been used to deliver chemotherapeutics to cancer cells, ${ }^{7}$ but their utility is limited by the reliance on non-biologically compatible metal ions. We report here the synthesis of NCPs by linking nitrogen-containing bisphosphonates (N-BPs) with $\mathrm{Ca}^{2+}$, one of the most biologically prevalent ions, and targeted delivery of N-BPs to cancer cells with surface-modified NCPs.

N-BPs inhibit osteoclast-mediated bone resorption and are used clinically to treat patients with osteoporosis and bone metastases of several cancers. ${ }^{8}$ Recently, N-BPs have been shown to be effective antitumor agents, by inhibiting farnesyl pyrophosphate synthase, a key enzyme in the biosynthetic mevalonate pathway, which in turn induces caspase-dependent apoptosis, inhibits matrix metalloproteinase activity, and down-regulates $\alpha_{v} \beta_{3}$ and $\alpha_{v} \beta_{5}$ integrins. ${ }^{9}$ However, N-BPs are not effective anticancer drugs due to their unfavorable pharmacokinetics, as the majority of the injected N-BP dose either binds to the bones or is quickly cleared via renal filtration. In this work, we have incorporated two N-BPs, pamidronate (Pam) and zoledronate (Zol), directly into crystalline NCPs using $\mathrm{Ca}^{2+}$ ions as the metal-connecting points, and demonstrated the targeted delivery of N-BPs to cancer cells with surface-modified NCPs (Scheme 1). The NCP formulations have several advantages, including the crystalline nature, exceptionally high drug loadings, ${ }^{10}$ controllable compositions, shapes, and sizes, and intrinsic biodegradability. ${ }^{11}$

A solvothermal reaction between $\mathrm{Na}_{2} \mathbf{P a m}$ and $\mathrm{CaCl}_{2} \cdot 2 \mathrm{H}_{2} \mathrm{O}$ in diethylformamide (DEF)/ $\mathrm{H}_{2} \mathrm{O}$ afforded single crystals of Ca-Pam with the formula of $\left[\mathrm{Ca}\left(\mathrm{H}_{2}-\mathrm{Pam}\right)\left(\mathrm{H}_{2} \mathrm{O}\right)\right] \cdot \mathrm{H}_{2} \mathrm{O} . \ddagger \mathrm{A}$ similar reaction between $\mathrm{H}_{4}-\mathrm{Zol}$ and $\mathrm{CaCl}_{2} \cdot 2 \mathrm{H}_{2} \mathrm{O}$ in dimethylformamide $(\mathrm{DMF}) / \mathrm{H}_{2} \mathrm{O}$ gave

\footnotetext{
$\dagger$ Electronic supplementary information (ESI) available: Experimental procedures, X-ray crystallographic data, SEM and TEM images, IC 50 values, and confocal images. CCDC 856980 and 856981 . For ESI and crystallographic data in CIF or other electronic format see DOI: $10.1039 / \mathrm{c} 2 \mathrm{cc} 17635 \mathrm{a}$

This journal is () The Royal Society of Chemistry 2012

Correspondence to: Wenbin Lin, wlin@unc.edu.
} 
single crystals of $\mathbf{C a}-\mathbf{Z o l}$ with the formula of $\left[\mathrm{Ca}\left(\mathrm{H}_{2}-\mathbf{Z o l}\right)\left(\mathrm{H}_{2} \mathrm{O}\right)\right] .{ }^{\S} \mathbf{C a}-\mathbf{P a m}$ and $\mathbf{C a}-\mathbf{Z o l}$ are isostructural, and adopt a 1-D polymeric structure. The $\mathrm{Ca}^{2+}$ center is coordinated by seven oxygen atoms, one from the water molecule and the other six from the phosphonate groups, to form a 1-D polymer (Fig. 1). The phase purity of Ca-Pam and Ca-Zol was supported by their powder X-ray diffraction (PXRD) patterns.

Crystalline particles of Ca-Pam (1) were synthesized in 70\% yield by a solvothermal reaction between $\mathrm{H}_{4}-\mathrm{Pam}$ and $\mathrm{CaCl}_{2} \cdot 2 \mathrm{H}_{2} \mathrm{O}$ in water. SEM and TEM images show that $\mathbf{1}$ forms rod-like particles of $\sim 80 \times 80 \times 1000 \mathrm{~nm}$ in dimensions (Fig. 2a and b). Pam loading was determined to be $75.5 \mathrm{wt} \%$ by UV-Vis spectroscopy via complexation with $\mathrm{Fe}^{3+}$ ions (expected $80.0 \mathrm{wt} \%$ ). Microwave heating of a solution of $\mathrm{H}_{4}-\mathbf{Z o l}$ and $\mathrm{CaCl}_{2} \cdot 2 \mathrm{H}_{2} \mathrm{O}$ in DMF/ $\mathrm{H}_{2} \mathrm{O}$ at $100{ }^{\circ} \mathrm{C}$ led to crystalline particles of $\mathbf{C a}-\mathbf{Z o l}(2)$ which also adopts a rod-like morphology of $\sim 70 \times 70 \times 1000 \mathrm{~nm}$ in dimensions (Fig. $2 \mathrm{~d}$ and e). 2 has a Zol loading of $75.7 \mathrm{wt} \%$ as measured by UV-Vis spectroscopy (expected $83.0 \mathrm{wt} \%$ ). The synthesis of $\mathbf{1}$ and 2 is highly reproducible, and their formulations were supported by thermogravimetric analysis (TGA). PXRD results indicated that $\mathbf{1}$ and $\mathbf{2}$ share the same phase as their bulk crystals.

The as-synthesized particles of $\mathbf{1}$ and $\mathbf{2}$ are stable in water but decompose gradually in $5 \mathrm{mM}$ phosphate-buffered saline (PBS) solution at $37^{\circ} \mathrm{C}$ with a half-life $\left(t_{1 / 2}\right)$ of $6.3 \mathrm{~h}$ and $15.8 \mathrm{~h}$, respectively (Fig. 2a). To slow down the dissolution of N-BPs in biologically relevant media, we coated these particles with single lipid bilayers (SLBs) containing $1: 1$ (by mol) DOTAP/DOPE (DOTAP = dioleoyl trimethylammonium propane and DOPE $=$ dioleoyl $\mathrm{L}-\mathrm{a}-$ phosphatidylethanolamine). The SLBs not only stabilize the particles but also impart biocompatibility. ${ }^{12}$ Liposomes of $100-110 \mathrm{~nm}$ in diameter with a $\zeta$ potential of $55 \pm 10 \mathrm{mV}$ were mixed with 1 or $\mathbf{2}$ in $10 \mathrm{mM}$ aq. $\mathrm{KCl}$ with a particle:liposome weight ratio of $4: 1$ to afford lipid-coated NCPs. The presence of SLBs was confirmed by dynamic light scattering (DLS) measurements, TGA, TEM, and N-BP release data. Whereas the as-synthesized particles possess negative $\zeta$ potentials $(-22.1 \pm 2 \mathrm{mV}$ for $\mathbf{1}$ and $-32.5 \pm 2 \mathrm{mV}$ for $\mathbf{2}$ ), 1@lipid and 2@lipid have $\zeta$ potential values of $54.4 \pm 6 \mathrm{mV}$ and $56.2 \pm 4 \mathrm{mV}$, respectively. TGA gave $8-10 \mathrm{wt} \%$ additional organic weight loss in the $200-500{ }^{\circ} \mathrm{C}$ temperature range for the lipid coating. Coverage of individual particles with SLBs was supported by TEM studies using uranyl acetate stain. Dark rings were observed around the lipid-coated NCP particles due to the interaction between uranyl ions and the phosphate groups of DOPE (Fig. $2 \mathrm{c}$ and $\mathrm{f}$ ). Drug loadings after lipid coating were determined to be $65.1 \mathrm{wt} \%$ and $67.0 \mathrm{wt} \%$ for1@ lipid and 2@ lipid, respectively. The release profiles for 1@ lipid and 2@lipid in 5 $\mathrm{mM}$ PBS at $37{ }^{\circ} \mathrm{C}$ gave a $t_{1 / 2}$ of $20.1 \mathrm{~h}$ and $37.7 \mathrm{~h}$, with complete release achieved in $120 \mathrm{~h}$ and $140 \mathrm{~h}$, respectively. The initial burst release of the cargoes (Fig. 3a and b) probably results from the uncoated or incompletely coated particles (Table 1).

Anisamide (AA) was conjugated to DOPE via the primary amine group as the targeting ligand because AA is known to target $\sigma$ receptors that are overexpressed by many human cancer cells, including H460 human non-small cell lung cancer cells and AsPC-1 human pancreatic cancer cells. ${ }^{13} 10 \mathrm{~mol} \%$ of DOPE-AA was incorporated into the liposomal formulation, and the resulting $1 @$ lipid-AA and $2 @$ lipid-AA had similar sizes, drug loadings, and $\zeta$ potentials as their undoped counterparts (Fig. 3c and d).

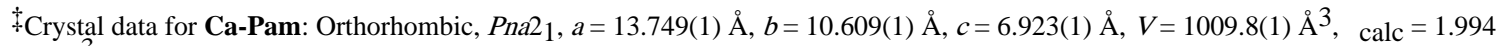
$\mathrm{g} \mathrm{cm}^{-3} \cdot R_{1}=0.036, \mathrm{w} R_{2}=0.095$.

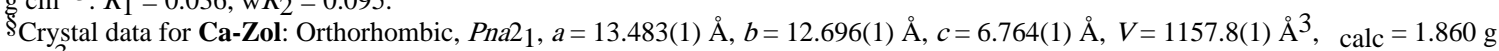
$\mathrm{cm}^{-3} \cdot R_{1}=0.059, \mathrm{w} R_{2}=0.143$.
} 
We performed in vitro cytotoxicity assays on $\mathrm{H} 460$ cells. The free drug and as-synthesized NCPs $\mathbf{1}$ and $\mathbf{2}$ do not lead to any appreciable cell death, as a result of their inability to enter the cells. However, $1 @$ lipid and $2 @$ lipid showed significantly higher potency, with $\mathrm{IC}_{50}$ (50\% inhibitory concentration) values of $4.5 \pm 3.4$ and $1.0 \pm 0.5 \mu \mathrm{M}$, respectively. $1 @$ lipidAA and 2@lipid-AA have slightly lower $\mathrm{IC}_{50}$ values of $1.0 \pm 0.1$ and $0.84 \pm 0.2 \mu \mathrm{M}$, respectively. Lipid-coated and AA-targeted NCPs can thus be effectively internalized by cells, presumably via fusion of the cationic lipid bilayers with cell membranes and $\sigma$ receptor-mediated endocytosis. We also performed in vitro cytotoxicity assays on AsPC-1 cells. No cell death was observed for Pam, 1, 1@lipid, and 1@lipid-AA, indicating that Pam does not induce apoptosis in AsPC-1 cells. However, 2@lipid and 2@lipid-AA gave $\mathrm{IC}_{50}$ values of $6.9 \pm 1.4$ and $3.6 \pm 2.3 \mu \mathrm{M}$, respectively. The inability of $\mathbf{1} @$ lipid and 1 @lipid-AA to induce apoptosis in AsPC-1 cells provides convincing evidence that the N$\mathrm{BPs}$, not $\mathrm{Ca}^{2+}$ ions, are responsible for the observed cytotoxicity.

The targeting capability of the NCPs was further supported by laser scanning confocal fluorescence microscopy studies. $5 \mathrm{~mol} \%$ DOPE-rhodamine was doped into the liposomal formulation for imaging studies. The cells were also stained with DRAQ5 nuclear stain and Annexin V-FITC apoptosis marker. As shown in Fig. 4, significant fluorescence from rhodamine (red) and FITC (green) was observed in the confocal z section images of H460 cells incubated with $1 @$ lipid-AA, indicating increased apoptosis due to enhanced cell uptake of the targeted particles. In comparison, much weaker red and green signals were observed for H460 cells incubated with $1 @$ lipid.

In summary, we have developed a general strategy to deliver bisphosphonates to cancer cells by incorporation into crystal-line NCPs at exceptionally high drug loadings. Lipid-coated and anisamide-targeted NCPs displayed superior anti-tumor efficacy compared to the assynthesized particles or free bisphosphonates in vitro against human lung and pancreatic cancer cells. NCPs thus provide a generalized approach for delivering otherwise ineffective chemotherapeutics with unfavorable pharmacokinetics to cancer cells.

\section{Acknowledgments}

We thank NIH-NCI (U01-CA151455) for financial support.

\section{Notes and references}

1. (a) Furukawa H, Ko N, Go YB, Aratani N, Choi SB, Choi E, Yazaydin AO, Snurr RQ, O'Keeffe M, Kim J, Yaghi OM. Science. 2010; 329:424. [PubMed: 20595583] (b) Ma L, Mihalcik DJ, Lin W. J. Am. Chem. Soc. 2009; 131:4610. [PubMed: 19290636] (c) Yuan D, Zhao D, Sun D, Zhou HC. Angew. Chem., Int. Ed. 2010; 49:5357.(d) Bradshaw D, Warren JE, Rosseinsky MJ. Science. 2007; 315:977. [PubMed: 17303750] (e) Yang S, Lin X, Blake AJ, Walker GS, Hubberstey P, Champness NR, Schröder M. Nat. Chem. 2009; 1:487. [PubMed: 21378916]

2. (a) Ma L, Falkowski JM, Abney C, Lin W. Nat. Chem. 2010; 2:838. [PubMed: 20861899] (b) Lee J, Farha OK, Roberts J, Scheidt KA, Nguyen ST, Hupp JT. Chem. Soc. Rev. 2009; 38:1450. [PubMed: 19384447] (c) Wu C-D, Hu A, Zhang L, Lin W. J. Am. Chem. Soc. 2005; 127:8940. [PubMed: 15969557]

3. Evans OR, Lin W. Acc. Chem. Res. 2002; 35:511. [PubMed: 12118990]

4. Allendorf MD, Houk RJT, Andruszkiewicz L, Talin AA, Pikarsky J, Choudhury A, Gall KA, Hesketh PJ. J. Am. Chem. Soc. 2008; 130:14404. [PubMed: 18841964]

5. (a) D'Alessandro DMD, Smit B, Long JR. Angew. Chem., Int. Ed. 2010; 49:6058.(b) Xiang S-C, Zhang Z, Zhao C-G, Hong K, Zhao X, Ding D-R, Xie M-H, Wu C-D, Das MC, Gill R, Thomas KM, Chen B. Nat. Commun. 2011; 2:204. [PubMed: 21343922]

6. (a) Rieter WJ, Taylor KML, An H, Lin W, Lin W. J. Am. Chem. Soc. 2006; 128:9024. [PubMed: 16834362] (b) Taylor KML, Rieter WJ, Lin W. J. Am. Chem. Soc. 2008; 130:14358. [PubMed: 
18844356] (c) Horcajada P, Chalati T, Serre C, Gillet B, Sebrie C, Baati T, Eubank JF, Heurtaux D, Clayette P, Kreuz C, Chang J-S, Hwang YK, Marsaud V, Bories P-N, Cynober L, Gil S, Ferey G, Couvreur P, Gref R. Nat. Mater. 2010; 9:172. [PubMed: 20010827] (d) deKrafft KE, Xie Z, Cao G, Tran S, Ma L, Zhou OZ, Lin W. Angew. Chem., Int. Ed. 2009; 48:9901.(e) Liu D, Huxford RC, Lin W. Angew. Chem., Int. Ed. 2011; 50:3696.

7. (a) Rieter WJ, Pott KM, Taylor KML, Lin W. J. Am. Chem. Soc. 2008; 130:11584. [PubMed: 18686947] (b) Taylor-Pashow KML, Rocca JD, Xie Z, Tran S, Lin W. J. Am. Chem. Soc. 2009; 131:14261. [PubMed: 19807179]

8. Lipton A. Expert Opin. Pharmacother. 2011; 12:749. [PubMed: 21247359]

9. Green JR. Oncologist. 2004; 9:3. [PubMed: 15459425]

10. Kim J, Piao Y, Hyeon T. Chem. Soc. Rev. 2009; 38:372. [PubMed: 19169455]

11. (a) Champion JA, Mitragotri S. Proc. Natl. Acad. Sci. U. S. A. 2006; 103:4930. [PubMed: 16549762] (b) Yavuz MS, Cheng Y, Chen J, Cobley CM, Zhang Q, Rycenga M, Xie J, Kim C, Song KH, Schwartz AG, Wang LV, Xia Y. Nat. Mater. 2009; 8:935. [PubMed: 19881498]

12. (a) Gerasimov OV, Boomer JA, Qualls MM, Thompson DH. Adv. Drug Delivery Rev. 1999; 38:317.(b) Andresen TL, Jensen SS, Jørgensen K. Prog. Lipid Res. 2005; 44:68. [PubMed: 15748655] (c) Liu J, Jiang X, Ashley C, Brinker CJ. J. Am. Chem. Soc. 2009; 131:7567. [PubMed: 19445508] (d) Chen H, MacDonald RC, Li S, Krett NL, Rosen ST, O'Halloran TV. J. Am. Chem. Soc. 2006; 128:13348. [PubMed: 17031934] (e) Ashley CE, Carnes EC, Phillips GK, Padilla D, Durfee PN, Brown PA, Hanna TN, Liu J, Phillips B, Carter MB, Carroll NJ, Jiang X, Dunphy DR, Willman CL, Petsev DN, Evans DG, Parikh AN, Chackerian B, Wharton W, Peabody DS, Brinker CJ. Nat. Mater. 2011; 10:389-397. [PubMed: 21499315]

13. (a) Kashiwagi H, McDunn JE, Simon PO Jr, Goedegebuure PS, Xu J, Jones L, Chang K, Johnston F, Trinkaus K, Hotchkiss RS, Mach RH, Hawkins WG. Mol. Cancer. 2007; 6:48. [PubMed: 17631687] (b) Vilner BJ, John CS, Bowen WD. Cancer Res. 1995; 55:408. [PubMed: 7812973] 
a)

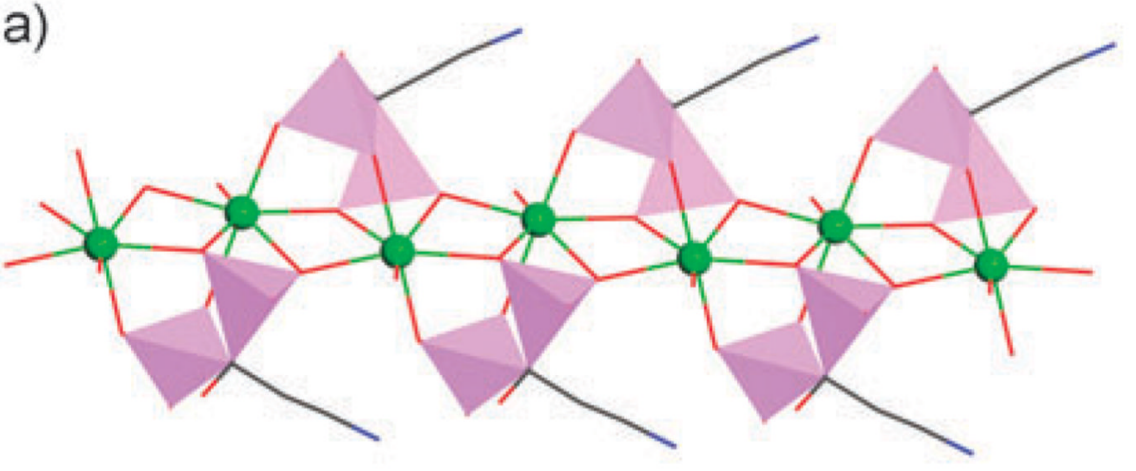

C)

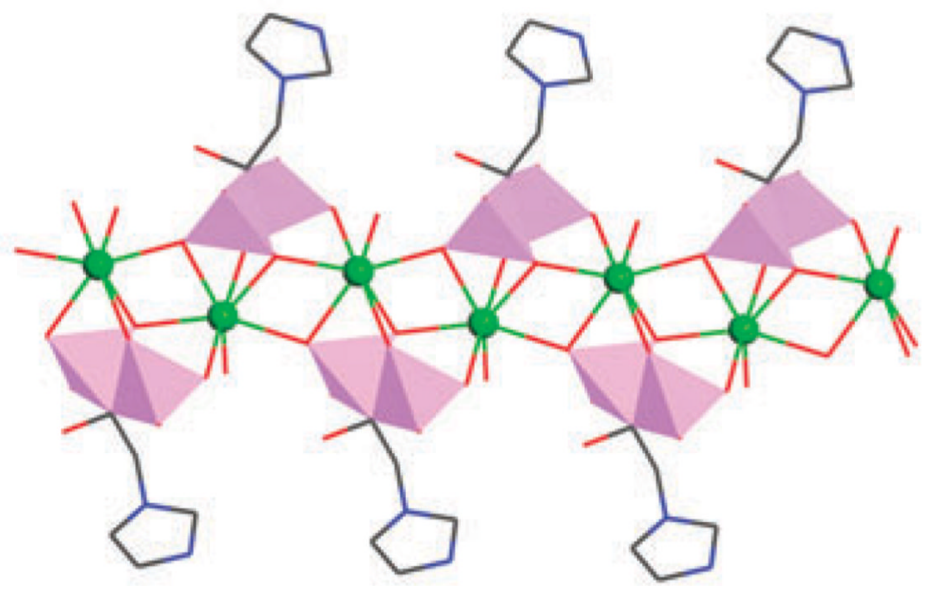

b)

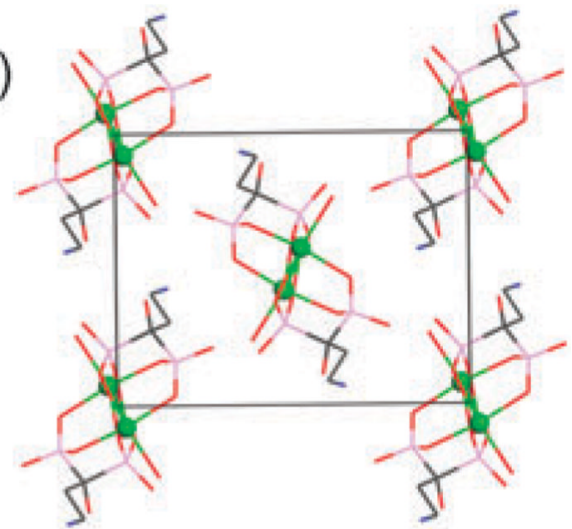

d)

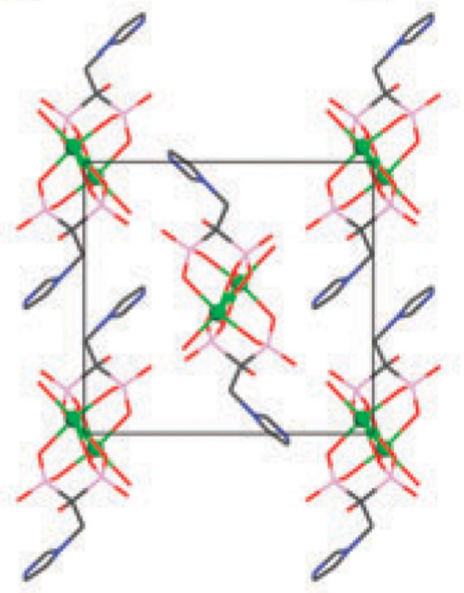

Fig. 1.

Side view of the 1-D polymeric structure of Ca-Pam (a) and Ca-Zol (c). Packing diagram of Ca-Pam (b) and Ca-Zol (d) as viewed down the $c$ axis. Ca: green; P: pink; N: blue; C: gray; O: red. Hydrogen atoms are omitted for clarity. 


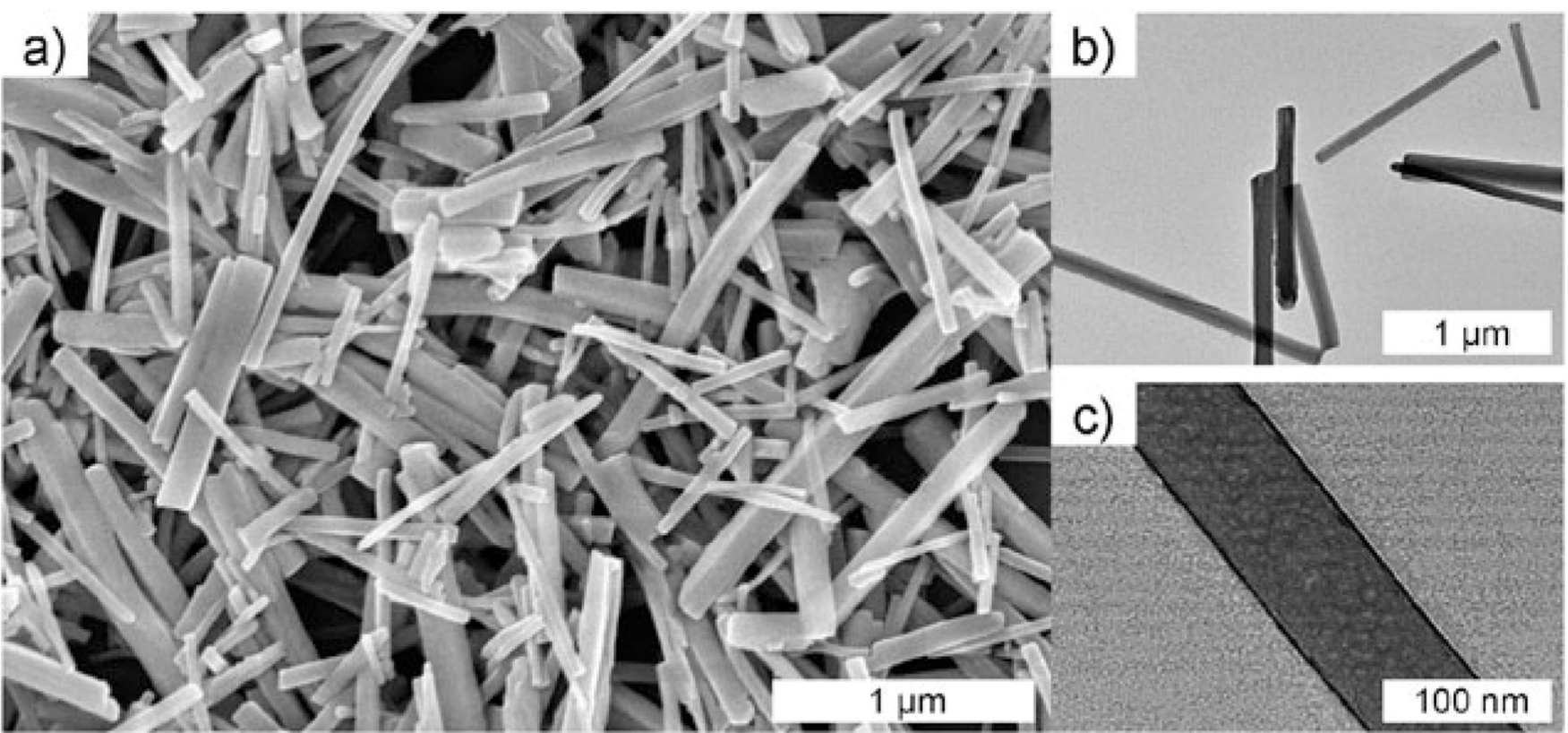

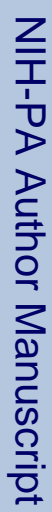

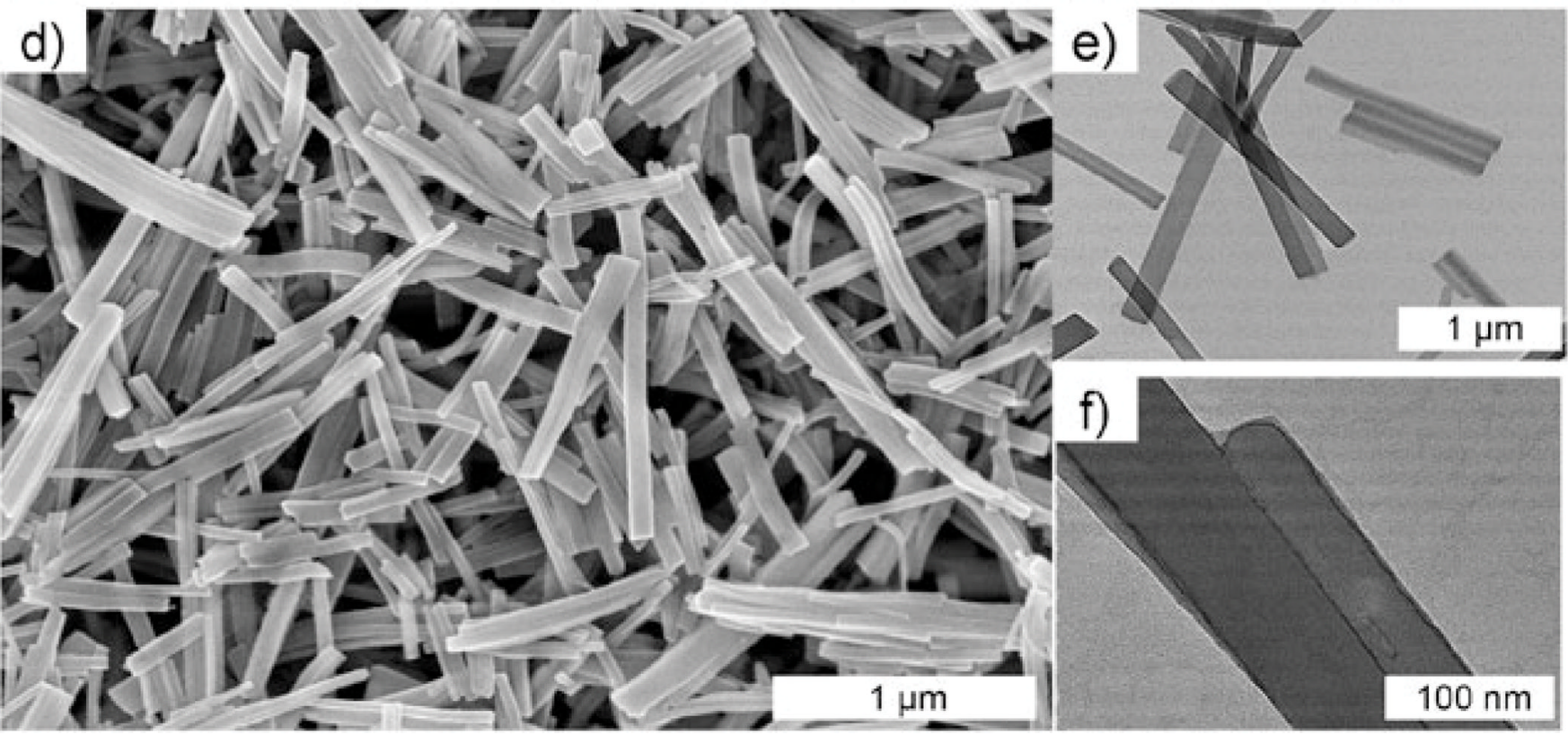

Fig. 2.

(a) SEM and (b) TEM image of 1. (c) TEM image of 1-lipid with uranyl stain. (d) SEM and (e) TEM images of 2. (f) TEM image of 2-lipid with uranyl stain. 
a)

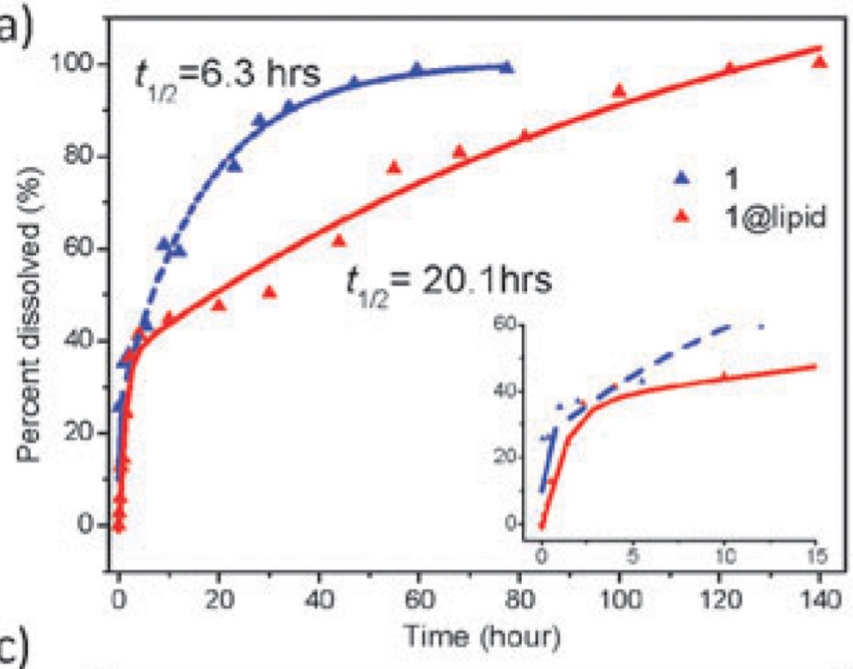

c)

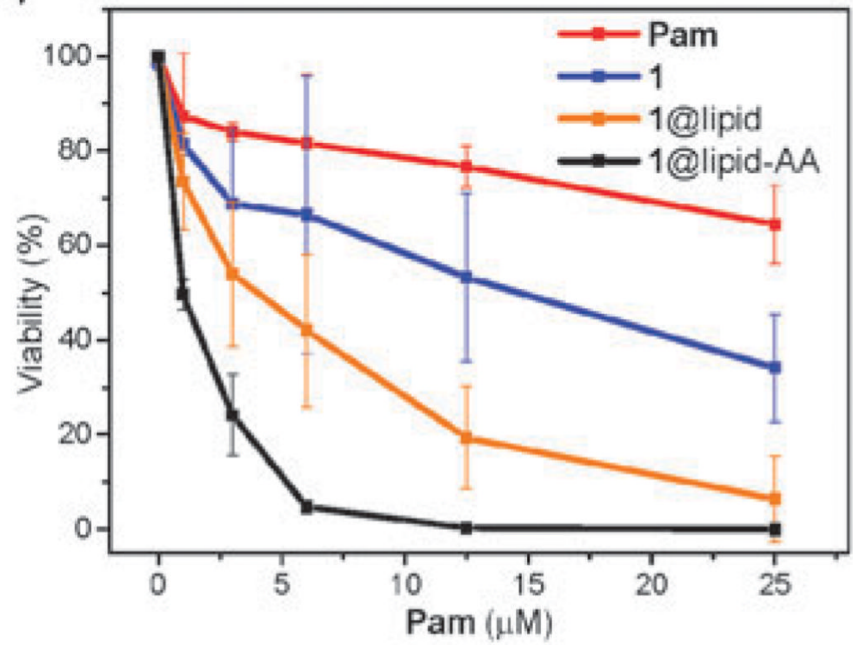

b)

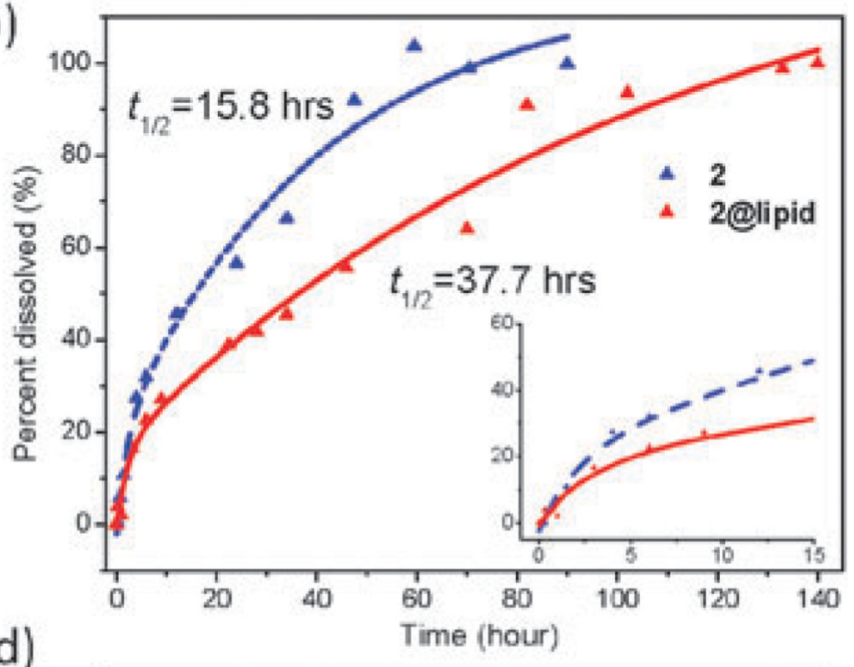

d)

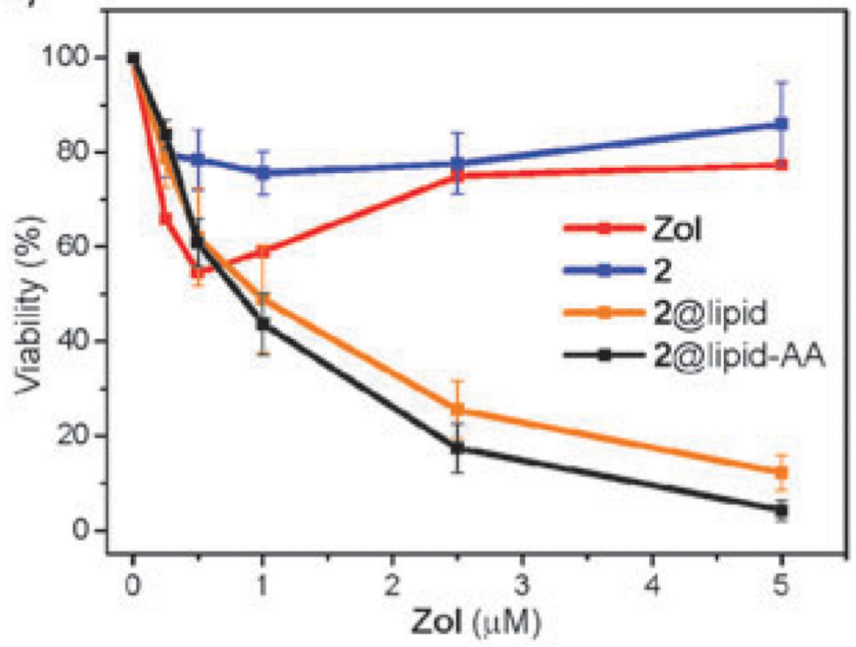

Fig. 3.

Release profiles of $\mathbf{1}$ and $\mathbf{1} @$ lipid (a) and $\mathbf{2}$ and $\mathbf{2} @$ lipid (b) in PBS at $37^{\circ} \mathrm{C}$. In vitro cytotoxicity assays of various Pam (c) and Zol (d) formulations against H460 cells. Error bars represent one standard deviation. 


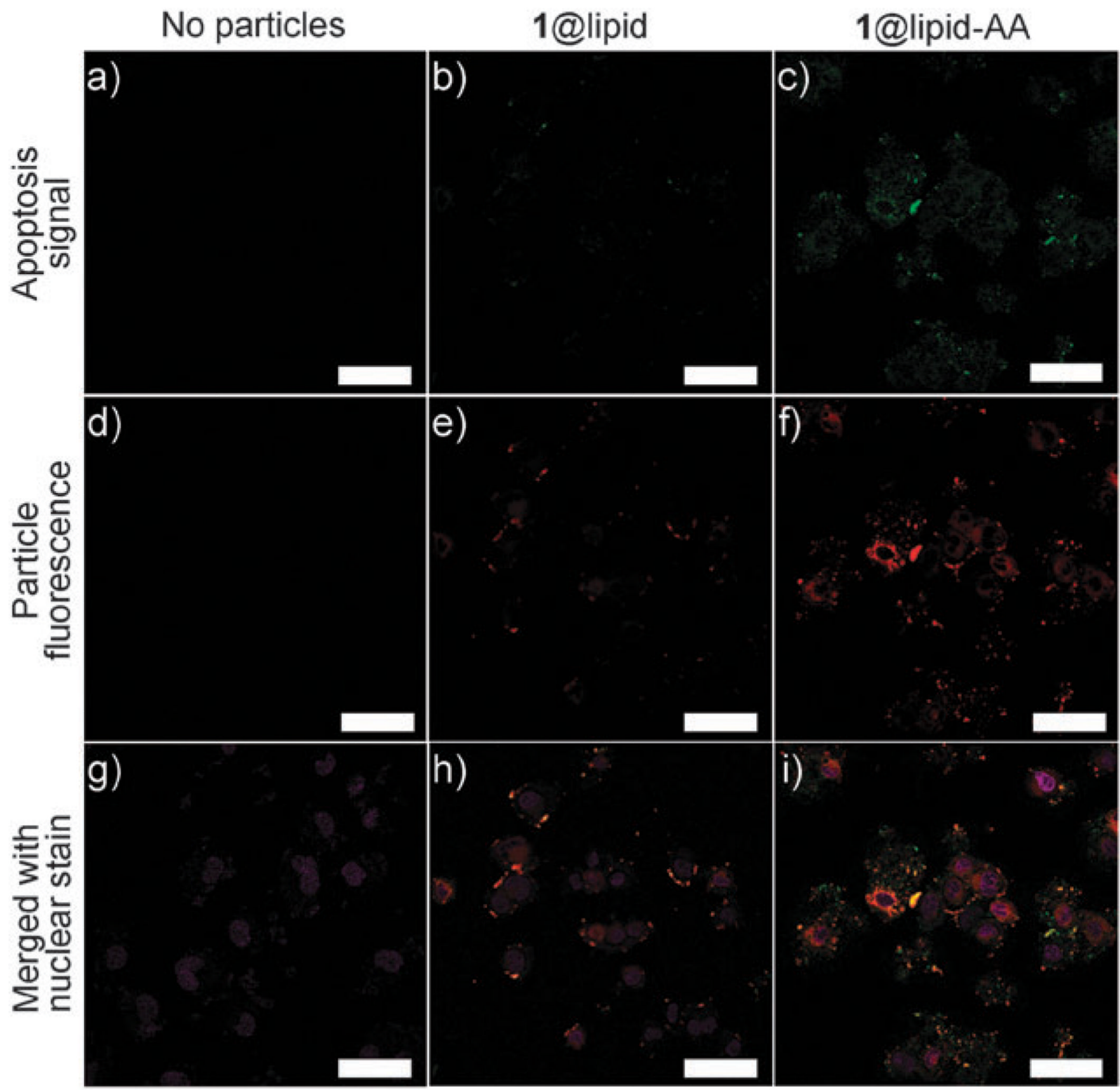

Fig. 4.

Fluorescence images of H460 cells incubated with no particles (a, d, g), $1 @$ lipid (b, e, h), and $1 @$ lipid-AA (c, f, i). Channels are: DRAQ5 nuclear stain (purple), Annexin V FITC conjugate early apoptosis stain (green), and DOPE-rhodamine from the particles (red). Scale bars are $40 \mu \mathrm{m}$. 


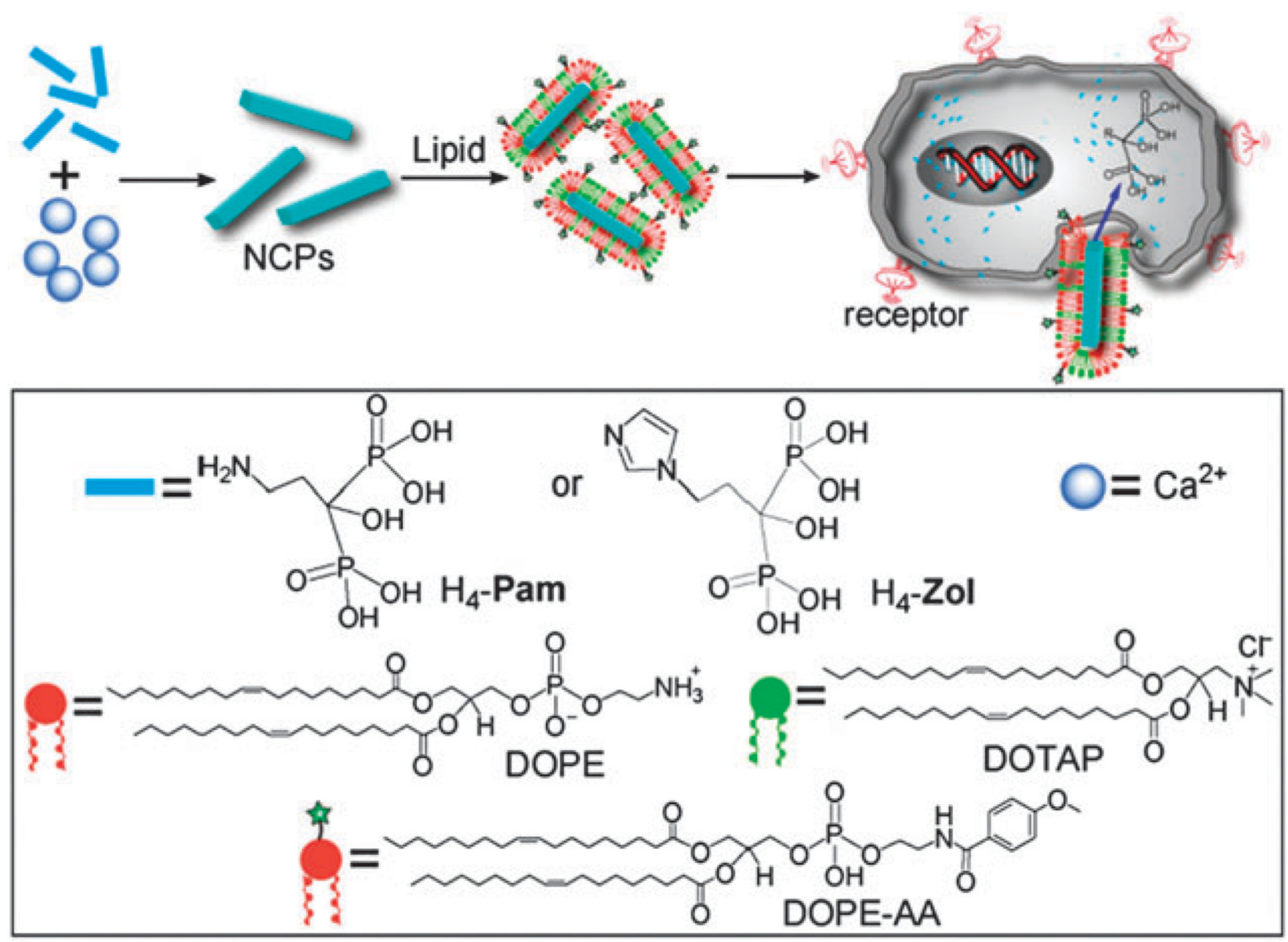

Scheme. 1.

Synthesis and surface functionalization of NCPs and their targeted delivery to cancer cells. 


\section{Table 1}

Characterization data for $\mathbf{1 , 2}$, and related particles

\begin{tabular}{|c|c|c|c|c|}
\hline Particle & $\zeta_{\mathrm{mV}}$ potential $^{a} /$ & $\begin{array}{l}\text { Drug loading } \\
\text { (wt\%) }\end{array}$ & $\begin{array}{l}\text { H460 cells } \\
\mathrm{IC}_{50} / \mu \mathrm{M}\end{array}$ & $\begin{array}{l}\text { AsPC-1 cells } \\
\mathrm{IC}_{50} / \mu \mathrm{M}\end{array}$ \\
\hline 1 & $-22.1 \pm 2$ & 75.5 & $13.0 \pm 12.0$ & $>20$ \\
\hline 1 lipid & $54.5 \pm 6$ & 65.1 & $4.5 \pm 3.4$ & $>20$ \\
\hline 1 lipid-AA & $55.3 \pm 6$ & 66.3 & $1.0 \pm 0.1$ & $>20$ \\
\hline 2 & $-32.5 \pm 2$ & 75.7 & $>5.0$ & $>10$ \\
\hline 2 lipid & $56.2 \pm 4$ & 67.0 & $1.0 \pm 0.5$ & $6.9 \pm 1.4$ \\
\hline 2 lipid-AA & $55.1 \pm 3$ & 69.3 & $0.84 \pm 0.2$ & $3.6 \pm 2.3$ \\
\hline
\end{tabular}

${ }^{a}$ Values in $10 \mathrm{mM}$ aq. $\mathrm{KCl}$. 